\title{
Bali Electrical Energy Demand: Forecast and Supply Strategies
}

\author{
W. G. Ariastina, I N. Setiawan and I N. S. Kumara \\ Udayana University, Bali \\ Contact: \\ W. G. Ariastina \\ Department of Electrical Engineering \\ Udayana University \\ Jimbaran, Bali - 80362 \\ Tel/Fax: 0361-239599, E-mail: w.ariastina@ee.unud.ac.id
}

\begin{abstract}
Abstrak
Untuk menjamin keberlangsungan dan ketersediaan suplai energi, khususnya energi listrik, analisa untuk memprediksi kebutuhan beban untuk masa mendatang baik secara lokal maupun nasional adalah sangat penting untuk dilakukan. Dengan mengetahui besarnya potensi kebutuhan beban untuk masa mendatang, maka rencana pemanfaatan potensi sumber-sumber energi yang tersedia serta strategi penyalurannya dapat disusun. Makalah ini membahas tentang prediksi kebutuhan energi listrik untuk daerah Bali dengan menggunakan model yang terintegrasi. Strategi pemenuhan beban dan potensi pemanfaatan sumber-sumber energi terbarukan juga dibahas dalam makalah ini.
\end{abstract}

Kata kunci : energi listrik,prediksi kebutuhan beban, strategi pemenuhan beban.

\begin{abstract}
In order to ensure a sustainable and secure energy supply, particularly for electrical energy, it is essential to look at the future energy demand locally and nationally. By knowing the potential future demand, the utilisation of potentially available energy resources and supply strategies could be planned. This paper discusses Bali electrical energy demand forecast using an integrated model. The supply strategies and potential utilisation of renewable energy resources to meet the electricity demand are also discussed in the paper.
\end{abstract}

Keywords: electrical energy, demand forecast, supply strategies.

\section{INTRODUCTION}

In order to overcome the possible energy crisis, the government of the Republic of Indonesia has released a National Energy Policies (NEP), known as "Kebijakan Energi Nasional" [1]. The NEP contains comprehensive and integrated regulations for all energy utility sectors. The operation of energy utility sectors, including the electricity sectors, must refer to the NEP. The main objective of the NEP is to establish a secure nation wide energy supply. Other objectives are to secure the availability of domestic energy, encouraging additional utilisation of energy sources and managing the energy resources rationally and continuously. In addition, the issued of NEP is aimed to control environmental conservation, providing low cost energy sources and to extend energy distribution to under developed areas, as well as to improve national capability in energy supply. 
As implementation of the NEP, an integrated objective, strategic policy and action plan has been clarified in a Blueprint of 2005-2025 National Energy Management (BPNEM) or "Blueprint Pengelolaan Energi Nasional 2005-2025" [2]. The integrated objectives of the BPNEM include achievement of 95\% national electrification ratio and a secure national energy supply in year 2025 . Other goals are an improvement in purchasing ability of national community, realisation of energy infrastructure for oil fuel, gas, coal and electricity, and an existence of economically energy price.

Optimal utilisation of primary energy mixture is an approach to achieve a secure energy supply in year 2025 . By end of year 2025, it is expected that the national utilisation of oil fuel decreases to $26.2 \%$, the national consumption of natural gas increases to $30.6 \%$, and that of coal increases to $32.7 \%$. Moreover, it is expected that the utilisation of geothermal energy increases to $3.8 \%$ and that of new and renewable energy (other than geothermal) increases to 4.4\%, in year 2025.

To ensure a sustainable and secure energy supply, particularly for electrical energy, it is essential to look at the future energy demand locally and nationally. By knowing the potential future demand, the utilisation of potentially available energy resources and supply strategies could be planned. This paper discusses Bali electrical energy demand forecast using an integrated model. The supply strategies and potential renewable energy to meet the electricity demand are also discussed in the paper.

\section{FORECAST OF ELECTRICAL ENERGY DEMAND}

Forecasting method for electrical energy demand presented in this paper is an integrated model that combines analytical method and econometrical analyses. The method is based on macroeconomic assumptions, where regional Gross Domestic Product (GDP) is used as an indicator of economic growth within the area. An increased in regional GDP is assumed to increase the needs of electrical energy, due to utilisation of additional electrical appliances.

Application of the method requires a separation of the electricity consumers into four different sectors, which are domestic, commercial, public and industrial. The total electrical energy demand for the area is predicted by summing the energy demand of the four sectors. Table 1 shows the regional GDP of Bali based on price in year 2000.

Table 1: Bali Regional GDP for year 2000-2006 (in Rp.) based on price in year 2000 [3,4,5]

\begin{tabular}{|ccccc|}
\hline Year & Domestic & Commercial & Public & Industrial \\
\hline 2000 & $3,744,330.37$ & $8,599,179.71$ & $2,322,297.17$ & $2,602,421.21$ \\
2001 & $3,956,779.00$ & $8,754,588.79$ & $2,426,671.24$ & $2,741,836.28$ \\
2002 & $4,101,821.20$ & $8,882,993.42$ & $2,550,345.65$ & $2,888,700.43$ \\
2003 & $4,250,687.77$ & $9,148,368.98$ & $2,692,966.39$ & $2,988,872.70$ \\
2004 & $4,406,176.32$ & $9,628,554.53$ & $2,815,563.35$ & $3,112,949.60$ \\
2005 & $4,591,023.82$ & $10,256,775.88$ & $2,950,414.91$ & $3,274,230.18$ \\
\hline 2006 & $4,779,419.37$ & $10,827,271.22$ & $3,155,359.78$ & $3,422,628.91$ \\
\hline
\end{tabular}

\subsection{Consumer number growth}

The growth of consumer number per sector is assumed to be affected by the GDP growth of the associated sector. For example, the growth of domestic consumer number is expressed by domestic consumer factor (a ratio of domestic consumer growth and the GDP growth of the domestic sector). Thus the future number of consumer for domestic sector can be predicted by using a mathematical expression as follow:

$$
\text { Pel. } R_{t}=\text { Pel. } R_{t-1} *\left[1+\left(C p_{R} * G_{P D R B R} / 100\right)\right]
$$


where:
Pel. $R_{\mathrm{t}} \quad=$ Number of domestic consumer in year $\mathrm{t}$.
Pel. $\mathrm{R}_{\mathrm{t}-1} \quad=$ Number of domestic consumer in year $\mathrm{t}-1$.
$\mathrm{Cp}_{\mathrm{R}} \quad=$ Domestic consumer factor.
GPDRB $=$ GDP growth of the domestic sector $(\%)$.

Predicting the consumer number growth for other sectors then can be carried out using similar equation. The electricity consumer number for each sector is presented in Table 2.

Table 2: Number of electricity consumer per sector for year 2000-2007 [3,4,5]

\begin{tabular}{|rrrrrr|}
\hline Year & Domestic & Commercial & \multicolumn{1}{c}{ Public } & Industrial & \multicolumn{1}{c|}{ Total } \\
2000 & 516,609 & 37,574 & 18,833 & 633 & $\mathbf{5 7 3 , 6 4 9}$ \\
2001 & 534,619 & 41,721 & 19,531 & 646 & $\mathbf{5 9 6 , 5 1 7}$ \\
2002 & 552,582 & 45,292 & 20,301 & 645 & $\mathbf{6 1 8 , 8 2 0}$ \\
2003 & 565,714 & 48,108 & 20,900 & 650 & $\mathbf{6 3 5 , 3 7 2}$ \\
2004 & 587,705 & 49,337 & 22,673 & 608 & $\mathbf{6 6 0 , 3 2 3}$ \\
2005 & 589,524 & 49,742 & 22,782 & 610 & $\mathbf{6 6 2 , 6 5 8}$ \\
2006 & 609,657 & 52,526 & 23,949 & 624 & $\mathbf{6 8 6 , 7 5 6}$ \\
2007 & 619,037 & 56,033 & 24,804 & 614 & $\mathbf{7 0 0 , 4 8 8}$ \\
\hline
\end{tabular}

The forecast of total number of electricity consumer is the summation of the predicted consumer number of the four sectors. The mathematical expression can be written as follow:

$$
\text { Pel. } t \quad=\text { Pel. } R_{t}+\text { Pel. } K_{t}+\text { Pel. } P_{t}+\text { Pel. } I_{t}
$$

where:

Pel.t $=$ Forecast of the total consumer number in year $\mathrm{t}$.

Pel. $R_{\mathrm{t}}=$ Forecast of the domestic consumer number in year $\mathrm{t}$.

Pel. $\mathrm{K}_{\mathrm{t}}=$ Forecast of the commercial consumer number in year $\mathrm{t}$

Pel. $P_{t}=$ Forecast of the public consumer number in year $\mathrm{t}$.

Pel. $\mathrm{I}_{\mathrm{t}}=$ Forecast of the industrial consumer number in year $\mathrm{t}$.

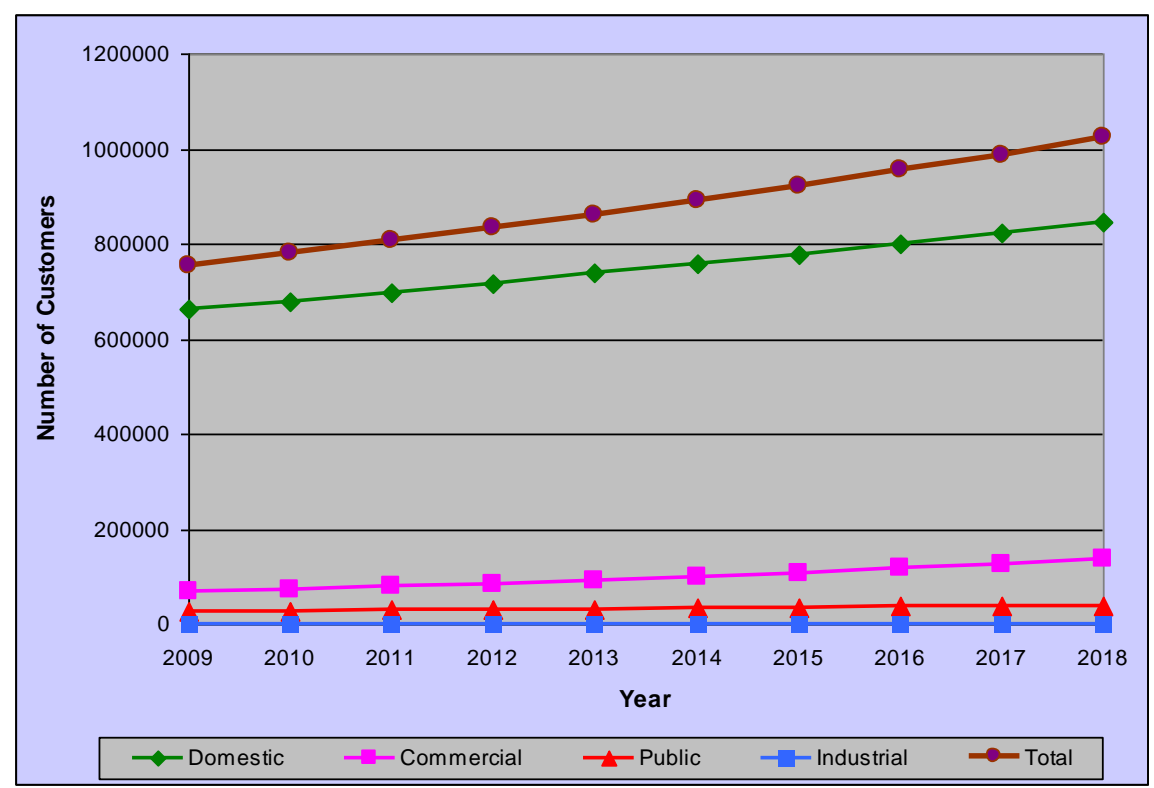

Figure 1: Forecast of electricity consumer number per sector for year 2009-2018

Figure 1 shows forecast of electricity consumer number for each sector from year 2009 to 2018. It can be seen that the consumer of domestic sector has the highest number, followed respectively by commercial, public and industrial sectors. At the end of year 2018, it is predicted that the number of 
electricity consumer for domestic sector may reach more than 845,000 . For three other sectors, at the end of year 2018, the consumer number would reach more than 136,000, 39,000, and 760 respectively for commercial, public and industrial. The total consumer at the time would reach more than $1,000,000$.

Electricity consumer number of domestic sector is predicted to increase with an average growth of $2.76 \%$ per annum, while that of commercial sector is predicted to increase with a yearly average growth of $8.31 \%$. The consumer number of public and industrial sectors is predicted to grow with an average of $4.32 \%$ and $1.74 \%$ per year, respectively. In total, during year 2009 to 2018, the electricity consumer number is predicted to increase by $3.38 \%$ per year.

\subsection{Electrical energy demand growth}

The energy utilisation growth for each sector is assumed to be affected by the sum of the GDP growth and the extra energy needs for additional new consumer. For instance, the energy utilisation growth for the domestic consumer is represented by energy elasticity of domestic sector (a ratio of the energy utilisation growth of domestic sector and the GDP growth of the domestic sector). Thus the future energy demand for domestic sector can be calculated as follow:

$$
E R_{t}=\left\{E R_{t-1} *\left[1+\left(C_{R} * G_{P D R B R} / 100\right)\right]\right\}+\left(\Delta P e l . R_{t} * U K R\right)
$$

where:

$$
\begin{array}{ll}
\mathrm{ER}_{\mathrm{t.}} & =\text { Energy utilisation of domestic consumer in year } \mathrm{t} . \\
\mathrm{ER}_{\mathrm{t}-1} & =\text { Energy utilisation of domestic consumer in year } \mathrm{t}-1 . \\
\Delta \mathrm{Pel} . \mathrm{R}_{\mathrm{t}} & =\text { The growth of the domestic consumer number in year } \mathrm{t} . \\
\mathrm{UKR} & =\text { Average energy consumption of domestic consumer. } \\
\mathrm{Ce}_{\mathrm{R}} & =\text { Energy elasticity of domestic sector. } \\
\mathrm{G}_{\mathrm{PDRBR}} & =\text { GDP growth of the domestic sector }(\%) .
\end{array}
$$

Similarly, the electrical energy demand growth for other sectors then can be predicted using similar equation. Table 3 presents the electrical energy demand in GWh per sector for year 2000 to 2006.

Table 3: Electrical energy demand per sector for year 2000-2006 (in GWh) [3,4,5]

\begin{tabular}{|cccccc|}
\hline Year & Domestic & Commercial & Public & Industrial & Total \\
\hline 2000 & 612.84 & 687.01 & 64.82 & 75.95 & $1,440.62$ \\
\hline 2001 & 710.24 & 766.74 & 71.50 & 81.88 & $1,630.36$ \\
\hline 2002 & 752.76 & 751.89 & 76.40 & 72.76 & $1,653.81$ \\
2003 & 761.04 & 760.16 & 77.24 & 73.56 & $1,672.00$ \\
\hline 2004 & 838.39 & 878.62 & 102.34 & 76.42 & $1,895.77$ \\
\hline 2005 & 933.53 & 935.98 & 138.31 & 86.56 & $2,094.38$ \\
\hline 2006 & 951.93 & 938.67 & 147.05 & 87.39 & $2,125.04$ \\
\hline
\end{tabular}

The total future electrical energy need can be calculated by summation of the predicted energy need of the four sectors. The mathematical expression is:

$$
E T_{t}=E R_{t}+E K_{t}+E P_{t}+E I_{t}
$$

where:

$\mathrm{ET}_{\mathrm{t}}=$ Forecast of the total electrical energy need in year $\mathrm{t}$.

$\mathrm{ER}_{\mathrm{t}}=$ Forecast of the domestic electrical energy need in year $\mathrm{t}$.

$\mathrm{EK}_{\mathrm{t}}=$ Forecast of the commercial electrical energy need in year $\mathrm{t}$.

$\mathrm{EP}_{\mathrm{t}}=$ Forecast of the public electrical energy need in year $\mathrm{t}$.

$\mathrm{EI}_{\mathrm{t}} \quad=$ Forecast of the industrial electrical energy need in year $\mathrm{t}$. 
Figure 2 shows forecast of electrical energy demand for each sector from year 2009 to 2018. It is clear that the highest electrical energy utilisation is yielded by domestic sector and followed respectively by commercial, public and industrial sectors. At the end of year 2018, it is predicted that the electrical energy demand for domestic sector is higher than 2,600GWh. For three other sectors, at the end of year 2018, the electrical energy needs would reach higher than 2,000, 990, and 110GWh per year, respectively for commercial, public and industrial. The total energy demand at the time may be higher than 5,800GWh per year.

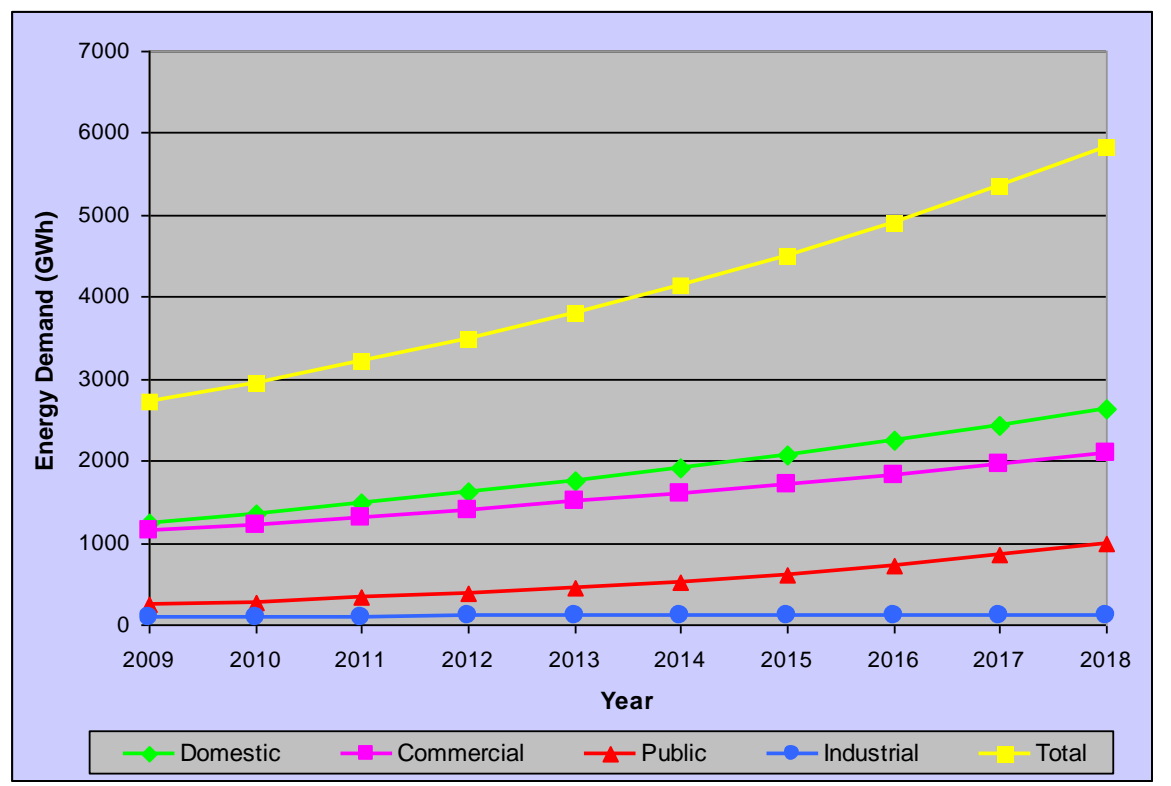

Figure 2: Forecast of electrical energy demand per sector for year 2009-2018 (in GWh)

Electrical energy need for domestic sector is predicted to increase with an average growth of $8.8 \%$ per annum, while that for commercial sector is predicted to increase with a yearly average growth of $6.9 \%$. The utilisation of electrical energy for public and industrial sectors is predicted to grow with an average of $17.3 \%$ and $2.6 \%$ per year, respectively. Thus during year 2009 to 2018 , the total utilisation of electrical energy is predicted to increase by $8.8 \%$ per year.

\section{FORECAST OF PEAK POWER DEMAND}

\subsection{Net Energy Demand}

The net demand of electrical energy is the summation of the energy demand and losses of energy due to transmission and distribution. Thus the net energy demand can be written as follow:

$$
\mathrm{EPt}=\frac{\mathrm{ETt}}{1-\mathrm{LTt}}
$$

where:

$$
\begin{array}{ll}
\mathrm{EP}_{\mathrm{t}} & =\text { Net energy demand in year } \mathrm{t} \\
\mathrm{ET}_{\mathrm{t}} & =\text { Total energy demand in year } \mathrm{t} \\
\mathrm{LT}_{\mathrm{t}} & =\text { Transmission and distribution losses in year } \mathrm{t}
\end{array}
$$

\subsection{Load Factor and Peak Power Demand}

Load factor is a ratio of average and peak loads. The average power demand is calculated by dividing the yearly net energy demand by 8760 hours. Thus the predicted peak power demand can be calculated using:

$$
013-5
$$




$$
\mathrm{BPt}=\frac{\mathrm{EP}_{\mathrm{t}}}{8760 \mathrm{LFt}} x 100
$$

where:

$$
\begin{aligned}
& \mathrm{BP}_{\mathrm{t}} \quad=\text { Peak load forecast for year } \mathrm{t}(\mathrm{MW}) \\
& \mathrm{EP}_{\mathrm{t}}=\text { Total energy production in year } \mathrm{t}(\mathrm{MWh}) \\
& \mathrm{LF}_{\mathrm{t}} \quad=\text { Load factor for year } \mathrm{t}(\%)
\end{aligned}
$$

\subsection{Assumptions}

A number of assumptions are considered for predicting Bali electrical peak power demand. It is assumed that the energy losses are decreasing by $0.02 \%$ per annum and the load factor is increasing by $0.5 \%$ per year.

\subsection{Power Balance}

The predicted power balance of Bali electrical system is presented in Table 4 and Figure 3 . In construction of the table and figure, the available generating capacities are assumed to be constant

\begin{tabular}{|c|c|c|c|c|c|c|c|c|c|c|c|}
\hline Description & Units & 2009 & 2010 & 2011 & 2012 & 2013 & 2014 & 2015 & 2016 & 2017 & 2018 \\
\hline Energy demand & GWh & $2,723.78$ & $2,959.57$ & $3,216.58$ & $3,497.05$ & $3,803.48$ & $4,138.71$ & $4,505.92$ & $4,908.77$ & $5,351.36$ & $5,838.40$ \\
\hline Losses & $\%$ & 6.27 & 6.25 & 6.22 & 6.19 & 6.16 & 6.13 & 6.10 & 6.07 & 6.04 & 6.01 \\
\hline Net energy demand & GWh & $2,894.56$ & $3,144.54$ & $3,416.66$ & $3,713.52$ & $4,037.78$ & $4,392.41$ & $4,780.78$ & $5,206.73$ & $5,674.58$ & $6,189.29$ \\
\hline Load factor & $\%$ & 63.30 & 63.80 & 65.10 & 66.40 & 67.70 & 69.00 & 70.30 & 71.60 & 72.90 & 74.20 \\
\hline Peak demand & MW & 522.01 & 562.64 & 599.12 & 638.43 & 680.85 & 726.69 & 776.32 & 830.13 & 888.59 & 952.21 \\
\hline Generating capacity & MW & 586.90 & 586.90 & 586.90 & 586.90 & 586.90 & 586.90 & 586.90 & 586.90 & 586.90 & 586.90 \\
\hline (N-1) condition & MW & 456.90 & 456.90 & 456.90 & 456.90 & 456.90 & 456.90 & 456.90 & 456.90 & 456.90 & 456.90 \\
\hline $\begin{array}{l}\text { Normal operating } \\
\text { reserve }\end{array}$ & MW & 64.89 & 24.26 & -12.22 & -51.53 & -93.95 & -139.79 & -189.42 & -243.23 & -301.69 & -365.31 \\
\hline $\begin{array}{l}\text { Reserve at (N-1) } \\
\text { condition }\end{array}$ & MW & -65.11 & -105.74 & -142.22 & -181.53 & -223.95 & -269.79 & -319.42 & -373.23 & -431.69 & -495.31 \\
\hline
\end{tabular}
throughout the 10 year range. The $(\mathrm{N}-1)$ condition is calculated based on the largest capacity of single generator in the system, which is 130MW (Gilimanuk power station).

Table 4: Predicted power balance of Bali electrical system for year 2009-2018

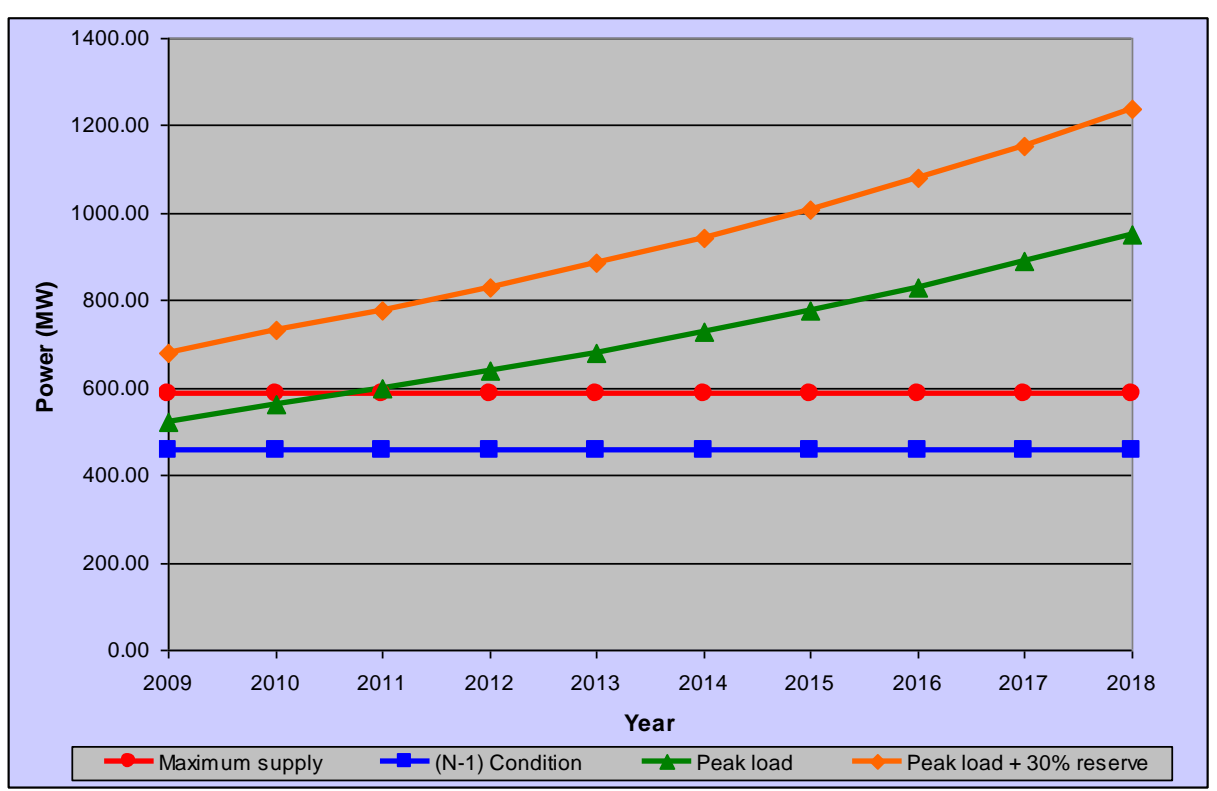

Figure 3: Predicted power balance for Bali electrical system 
From Table 4 and Figure 3, it is clear that if there is no additional capacity of supply, in year 2009 the electrical power system of Bali will not meet the $(\mathrm{N}-1)$ security condition. Under $\mathrm{N}-1$ condition, the electrical system has a power deficit of more than 65MW. It is also can be seen that at current available generating capacity, beginning in year 2011, the electrical power system of Bali will not meet the peak demand under normal condition. In year 2011, the electrical system has a power deficit of more than 12MW; and under (N-1) condition the power deficit would be more than $142 \mathrm{MW}$.

\section{SUPPLY STRATEGIES}

\subsection{Development Plan}

Following the increase in electrical energy need for Bali, it is required to develop new power plant or to increase the transfer capability of Java-Bali interconnected system. This is expected to be carried out by PT. PLN (Persero) and Independent Power Producer. Fuel of the new power plant should be other than oil, except for isolated generating system supplying off transmission grid areas. This is caused by the limited oil reserve and a higher production cost.

According to Bali Electrical Development Master Plan (Rencana Umum Ketenagalistrikan Daerah Provinsi Bali) [6], the suitable areas for the new power plant are within the diversity industrial zone, which is in North and East part of Bali. The North part of Bali Island has a wide unutilised land with small population and far from urban area. In addition, the coastal line of North Bali is sufficiently long and fairly flat. Similar conditions are also found in East part of Bali. Other possible location of an electric power plant is in Nusa Penida, a small island, approximately $12 \mathrm{kms}$ South East of Bali. Power delivery from the plant to Bali requires high voltage submarine cables across Badung Strait (a narrow sea between Bali and Nusa Penida islands).

Another option to secure the electricity energy supply for Bali is development of Java-Bali 500kV Extra High Voltage (EHV) overhead transmission line. This option was introduced, given the fact that the maximum power transfer of available $150 \mathrm{kV}$ submarine cables may insufficient to meet the load. The proposed EHV transmission line is started from Paiton EHV Substation to Banyuwangi (both in East Java), then across the Bali Strait (the strait between Java and Bali islands) to Gilimanuk (Bali). The transmission line is ended in future Kapal EHV Substation. The future transmission lines may deliver power up to 1000MVA, directly to Bali major load centre.

\subsection{Renewable Energy Resources}

A number of investigations of potential electrical energy resources in Bali have been completed. Results of the study show that there are possibilities in utilising several potential energy resources for generating electricity. The potential energy resources include river water stream for small and micro hydro power plant, wind energy and solar radiation. Other available resources include domestic wastes and geothermal energy.

In Bali, there is no large river with continuous water flow, like those in Java, Sumatera and Borneo. According to preceding studies, there are a number of potential rivers in Bali for small hydro electric power plant, such as Ayung and Unda Rivers. However, there is an increased in human activities upstream and along the river side that causes a reduction in rain water absorption area. Further impacts of the human activities may include decreasing in water stream volume and sustainability. This situation definitely influences and limits the operation of the future hydro electric power plant. Other constraint in hydro power plant development plan is uncontrollable water discharge flow due to tourism and sport activities along the river stream, such as fishing and fresh water rafting.

Research in potential wind energy application for electricity generation have been carried out in a number of villages, such as Klumpu Village in Nusa Penida Island and East Seraya in Karangasem District. In Klumpu Village, the average wind speed may reach $4.5 \mathrm{~m} / \mathrm{s}$. The wind mainly flows from 
the ocean (South) and the wind direction is mostly affected by the global wind instead of local wind. In East Seraya Village, the average measured wind speed was approximately $6.8 \mathrm{~m} / \mathrm{s}$. The wind mainly flows from the South and South-East, and is a resultant from the mount forced directed global wind and the coastal wind. The combination of the two produces a high speed wind from the South. Currently, a number of wind power generators have been installed and supplying electricity to the primary distribution grid in Nusa Penida.

One of the most widely used solar energy conversion technology is photovoltaic solar home system. The system is suitable for rural and remote areas and has been applied in a number of unelectrified areas surrounding Bali. The main constraint in application of the photovoltaic solar home system is a high investment cost and low production capacity. Limited availability of spare parts and lack of technicians may also be a drawback for utilisation of solar home system in most areas.

Preceding studies showed that there is potential biomass energy from domestic waste produced within four main districts in Bali, which are Denpasar, Badung, Gianyar and Tabanan. At present, a power plant that using methane gas from domestic waste, has been operated in IPST Sarbagita Suwung. The power plant is expected to produce a maximum electric power of 9.6MW. An additional capacity of $12 \mathrm{MW}$ may also be generated using a direct combustion generating system.

Bali has a number of potential areas for geothermal power plant, such as Banyu Wedang, Seririt, Penebel and Bedugul. Early investigations have been carried out in Banyu Wedang, Seririt and Penebel areas. More intensive and deep investigations covering geological, geophysical, and geochemical analysis have been conducted in Bedugul area. In the area, a number of temperature and exploration wells have been drilled. The investigations have showed that the proved reserve of geothermal energy may produce an approximate power of $225 \mathrm{MWe}$, with a total predicted reserved of $350-400 \mathrm{MWe}$. The main obstacle in developing the geothermal electric power plant is a mass public refusal.

\section{SUMMARY}

Forecasting results have shown that if there is no additional capacity of supply, in year 2009 the electrical power system of Bali will not meet the $(\mathrm{N}-1)$ security condition. Under $\mathrm{N}-1$ condition, the electrical system has a power deficit of more than $65 \mathrm{MW}$. The analysis results also show that at current generating capacity, beginning in year 2011, the electrical power system of Bali will not meet the peak demand under normal condition. In year 2011, the electrical system has a power deficit of more than 12MW; and under $(\mathrm{N}-1)$ condition the power deficit would be more than $142 \mathrm{MW}$. These figures demonstrate that Bali is currently in a state of electrical energy crisis.

A number of schemes have been introduced to meet the high grow electrical energy demand. These include development plan of new power plant and additional capacity of Java-Bali interconnected transmission system. The potential utilisations of renewable energy resources have also been explored. However, due to high investment cost and low production capacity, utilisation of renewable energy resources is still very small compared to the high demand growth. In conclusion, government, stake holders and community participations are urgently required to solve the energy crisis in Bali.

\section{REFERENCES}

[1] Departemen Energi dan Sumber Daya Mineral, "Kebijakan Energi Nasional”, Jakarta, 2004.

[2] Departemen Energi dan Sumber Daya Mineral, "Bluprint Pengelolaan Energi Nasional 20052025", Jakarta, 2005.

[3] Badan Pusat Statistik Provinsi Bali, "Bali Dalam Angka 2005”, Denpasar, 2005.

[4] Badan Pusat Statistik Provinsi Bali, "Bali Dalam Angka 2006", Denpasar, 2006.

[5] Badan Pusat Statistik Provinsi Bali, "Bali Dalam Angka 2007”, Denpasar, 2007. 
Bali Electrical Energy Demand: Forecast and Supply Strategies

[6] Badan Perencanaan Pembangunan Daerah Pemerintah Provinsi Bali, "Rencana Umum Ketenagalistrikan Daerah (RUKD) Provinsi Bali Tahun 2004”, Denpasar, 2004.

[7] PT PLN (Persero) Distribusi Bali, "Kajian Pasokan Energi Listrik Bali", Denpasar, 2005. 